\title{
The Exhaustion of Education and Its Educators:
}

\section{A Phenomenological Inquiry into Ontology, Anti-Black Racism \& the "Perversity" of Philosophic Creation}

\author{
Glenn M. Hudak \\ University of North Carolina - Greensboro
}

\section{CRISIS IN ONTOLOGY}

Education is exhausted. Why? Because education, as an ontological category, is still affected by a deep crisis rooted in colonial/Western ontology: a crisis revolving around anti-black racism and ontological exclusion that undoes the conceptual ties holding education together as a whole; this undoing of education exhausts education, whereby education becomes decisively divorced from its former associations in the world, i.e., politics and the public realm.

To be sure, one early marker noting anti-black racism in ontology has its roots in the writings of the revolutionary black thinker Frantz Fanon (1925-1961). Fanon scholar Lewis Gordon declares, "Fanon rejects ontology." "That is, Fanon flatly rejects the European category of ontology and its claim to inclusiveness. But, as Gordon stresses, "he does not reject the existential phenomenological impact of what he sees". ${ }^{2}$ As such, Fanon rejects the abstract category of ontology, a category with its "rigid, ontological commitments beyond the reality of the world in which one lives," "3ith its commitments and prejudices that deny his essence, that is, deny who he is as a black man. As such, what Fanon can't deny on the phenomenological level is the existential reality of his very life as he lives it. Hence, Fanon's challenge to Western ontology is grounded in the concrete reality of his existence, one that denied him an "essence" in the everyday world: the mundane. 
And what is the mundane that Fanon lived in? "There is the mundane," writes Fanon, "for the white and the mundane for the black." ${ }^{4}$ The mundane for the white is one of casual informality, of being able to stroll, so to speak, the streets in pleasant anonymity. The mundane for the black, on the other hand, is one of being caught in one's tracks, so to speak, by the white gaze; frozen as it were in one's place such that one becomes hyperconscious of one's most basic actions, such as lighting a cigarette. Indeed, here Fanon dreams of a "transformation of the everyday," where as, Fanon declares, "All I wanted was to be a man (sic) among other men. I wanted to come lithe and young into a world that was ours and help to build it together." ${ }^{5}$ As such, Fanon highlights the mundane as a key dimension in the struggle against anti-black colonialism.

We can say then that Fanon exists in the everyday world, yet he is not authorized to be a part of Being proper in the eyes of a colonial ontology. We might assert that Fanon exists in a state of overwhelming objectivity: to be "seen" by whites but not to be worthy of "mattering" in the everyday functioning of white society. For as Fanon writes in Black Skin, White Mask, "I arrived in the world anxious to make sense of things, my spirit filled with desire to be at the origin of the world, and here I discovered myself an object among other objects... Imprisoned in this overwhelming objectivity." This moment of "overwhelming objectivity" which renders Fanon an "object among objects" is what Gordon refers to as momentary epistemic closure. That is, "a moment of presumably complete knowledge of a phenomena. Such presumed knowledge closes off efforts at further inquiry. The result is what we shall call perverse anonymity."’ As Gordon explains, anonymity literally means to be nameless being nameless, however being nameless need not be seen as a negative trait. E.g., when we use the indefinite article " $a$," "a teacher" for instance, there is a positive valence to this anonymity. However, for blacks, "perversity" occurs when blacks are locked within epistemic closure, overdetermined such that there is no gap between who one is (their essence) and what one is (their social identity). Hence,"The schism between identity and being is destroyed, and the result is a necessary being, an 
overdetermined, "ontological" reality." As such, in the black mundane Fanon is seen as an "object among objects," predetermined by the "ontological reality" of anti-black racism. As an object among objects, Fanon is never spoken to but spoken about or without notice, called out of his private thoughts by a call that affirms his location in a prefigured ontological order.

And so it goes, well over a half of a century later, racism's perverse anonymity in the mundane remains as Fred Moten explains through the concept of "black sociality", in reference to the killing of Michael Brown on August 9 2014. For Moten, a "black sociality" that has rendered black lives in Fanon's terms, "objects among objects," hence yet another event of perverse anonymity. For as Moten exclaims, "what the drone Darren Wilson (the police officer) shot into that day was insurgent Black life walking down the street. I don't think he [Wilson] meant to violate the individual personhood of Michael Brown; he was shooting at mobile Black sociality walking down the street in a way that he understood implicitly constituted a threat to the order he represents and that he is sworn to protect...So when we say that Black lives matter I think what we do sometimes is obscure the fact that it's in fact Black lives that matters. That insurgent Black social life still constitutes profound threat to the already existing order of things." For Moten and Fanon, insurgent Black life manifests a deep "crisis" in the very fabric of white/colonial society's efforts to enforce a veil of perverse anonymity over the lives of Blacks.

But, we may ask, how does Fanon's dream of a transformation of the everyday, a mundane where he can walk lithe and free, become even thinkable within crisis of anti-black racism? To address this concern, I further ask that we consider the plausibility of ontology itself as transformational. Asking, how in the event of anti-black racism, does "crisis" operate as a moment of transformational ontology?

To investigate ontology in exhaustion and crisis, I turn to the essay "Exhaustion and Creation" by Brazilian philosopher Peter Pal Pelbart who observes, "It is crises that reveal to us the forces which have been at play and redistributes them, by answering the question: are the things going in 
the direction of life or death? Crisis is not the result of a series; rather it is a beginning that creates its own time and space... If crisis inhabits such a privileged place, it is because crisis is the means of 'putting one's own life into a form anew in a different way, and globally, departing from a rupture with the continuity or identity of the subject." 10

For Pelbart, crisis is lived as a moment of singularity, to be more precise here, an event that ruptures the continuity of his mundane, creating singularity in his life, an event. From Pelbart's perspective, Fanon's crisis puts his life into a form anew by rupturing the continuity of his very identity whereby in that moment of radical self-awareness he becomes jolted out of the mundane. The very same can be said of Moten regarding the singularity of the event of August 9, 2014 in Ferguson, Missouri and the death of Michael Brown. While crisis creates singularities, notice, however, that these events - for Fanon and Moten - are not equivalent, not the same, not equal as $\mathrm{A}=\mathrm{B}$. Rather, the key here is that these insurgent moments in Black life are isomorphic in structure, i.e., both share a similar structure, the "murder" (both literally and figuratively) of Black insurgent life: crisis to be sure, but singular events nonetheless.

Continuing, we can further tease out how this isomorphic structure is played out, so to speak, within the lives of insurgent Black lives. In a word, through "exhaustion." Drawing from the work of Gilles Deleuze, Pelbart points out the distinction between tiredness and exhaustion. "Tiredness is part of the dialectic of work and productivity: one rests and returns to activity...Exhaustion, on the other hand... is he (sic) who, having exhausted his purpose, is himself exhausted, such that this dissolution of the subject corresponds to the abolition of the world. Where tiredness perceives its activity as temporarily compromised and is prepared to resume it, exhaustion, on the other hand, is pure inactivity, pure testimonial." ${ }^{11}$ Crisis for insurgent Black life is exhaustion as, "pure inactivity, pure testimonial," it's murder!

As such, exhaustion is where one's very purpose and one's very being converge in a moment of "dissolution" whereby one's life is rarefacted, as life's meaning (and bodily energy) are lived as perhaps as a moment of dying 
without death, which is personified for Pelbart as a moment of insomnia, that being neither awake nor asleep, caught perhaps in Fanon's zone of nonbeing. Citing Deleuze, Pelbart clarifies this point of exhaustion as the space where 'it is necessary to 'breathe without oxygen' in order to profit from 'an energy more elementary and more rarefied." As such, exhaustion is indeed a "perversion" of life, especially in the form of the perverse anonymity of anti-black racism.

The irony here however is as Pelbart stresses, "The conclusion is clear: We create by exhausting the possible" (130). The rub is the very perversity of exhaustion, the rarefaction of life, is also a creation itself. As such, the perversity of creation-as-crisis is situated within the very event of exhausting, thereby exhausting the very philosophic concepts to be employed by ontology to express itself.

How is this so? How, for instance, can the perversity of anti-black racism be an event of philosophic creation? Pelbart continues, "Exhaustion may be a term that acutely defines, albeit enigmatically, the hesitant and unnecessary passage from catastrophe to creation...Exhaustion may be understood in the primary sense that Deleuze gave it: the exhaustion of the possible, in which the exhausted exhausts himself as a reservoir of possibles and has exhausted the possibles of language, as well as the potentialities of space and the very possibility of action." 12 Exhaustion here is perceived as an event that has rarefacted all possibles to action, in language, in space to think. Hence, "exhaustion more radically... an operation of disconnection ...Exhaustion undoes that which 'binds' us to the world, that 'imprisons' us in it and others, that 'captures' us with its words and images, that 'comforts' us with an allusion of entirety in which we have ceased to believe, even as we have remained attached to them." ${ }^{13}$ Anti-black racism as crisis in ontology exhausts the world, and with it, as Pelbart declares, "abolishes" the world and thereby "undoes us," undoes "that which binds." Exhaustion-as-crisis, as Pelbart infers, unravels, decisively divorces the bonds that imprison Fanon to be an "object among objects," unravels Moten to decisively divorce from humanist thinking and declare that it is Black lives that matter in the event.

As such, exhaustion doesn't simply rarefact, deplete ontological 
concepts, it undoes them as these very concepts become decisively divorced from their conceptual grounding, their mundane application in the world. This crisis in ontology not only speaks to the perversity of anti-black racism, but to a crisis in philosophy. As such, to speak of the perversity of ontology then, is to speak of the perversity of philosophy. This crisis in ontology and philosophy swirls around anti-black racism and this is a "problem." A "problem" in the most fundamental sense: i.e., the anti-black racism that Fanon points out which confronts ontology at its core: those very concepts that work to exclude the Black Lives as human amongst other humans with dignity and freedom. This perversity is an obstinacy on ontology's part to cover-up Black existence. This is catastrophic, but, as Pelbart argues, from exhaustion there is creation. Here we see creation on the philosophic plane occurs within this very field of ontological perversion. In short, philosophic creation is located within the very perversity of crisis, of anti-black racism! How so?

Here, following Pelbart, I draw from Deleuze and Guattari's What is Philosophy? In this text they state explicitly that, "philosophy is the art of forming, inventing, and fabricating concepts." ${ }^{14}$ Such that, "all concepts (created by philosophy) are connected to problems without which they would have no meaning and which can themselves only be isolated or understood as their solution emerges... [As such], in philosophy, concepts are only created as a function of problems which are thought to be badly understood or badly posed pedagogy." ${ }^{15}$ Crisis-in-ontology exhausts the possibles in the event by unraveling conceptual connections, as such nothing is possible as there is a complete stop to the mattering of things. As concepts become unraveled, they swirl within the event as new possibles are formed out of the very disjunction of the concepts from each other, i.e., everything becomes possible. This moment of exhaustion spawns new philosophic concepts from this disjunctive process whereby a synthesis is recorded in the philosophic plane amongst concepts that remain decisively divorced as a moment of "disjunctive synthesis", in Deleuzean terms. Here the new concept that is created in philosophy is not a mixture of prior concepts, or a dialectal 
synthesis in Hegelian terms of A and - A forming a new term B. Instead, concepts are profanated from their routine use as new possibilities arise from the event itself. Hence as noted, the concept is a "function of the problem" itself. The new concept that is created is immanent to the event, and not a transcendental supplement to the event. Here the event frames the problem that needs conceptualizing.

The problem within this context is: the crisis in ontology as pertains to the event of anti-black racism. The concept that addresses this problem in ontology, and hence, by extension, a philosophic creation, I submit is: education becoming decisively-divorced, hyphenated as to indicate the concept is a mode of becoming, i.e., being decisively-divorced. As a philosophic concept then, becoming decisively-divorced both addresses the problem of Black lives being decisively-divorced from ontology and acts as an immanent philosophic practice to decisively-divorce one from current anti-black conceptual constellations surrounding a specific event.

\section{CRISIS IN EDUCATION}

To illustrate the perversity of philosophic creation amid crisis and the creation of the concept of becoming decisively divorced within the educational context, I turn to a specific crisis in education: the event of Arendt's writing her "Reflections on Little Rock,"17 with its "A Reply to Critics" and "Crisis in Education." 18 Hereafter these texts are referred to as Reflections, Reply and Crisis. My aim in drawing upon Arendt's Crisis, Reflections, and Reply is to illustrate how the philosophic conception of education as becoming decisively-divorced is "created" within the event of Little Rock. By framing Arendt's writing within an event, I'm drawing from philosopher Erin Manning who emphasizes "that there is nothing outside or beyond the event, the aim is to create an account of experience that requires no omnipresence. The event is where experience actualizes." 19 That is, the event of Little Rock is actualized in the writing of Arendt and hence they illustrate how education becomes exhausted by the anti-black racism in Little Rock as well as the educator, in this case Arendt, who attempts to educate the public on Little Rock. 
As such Arendt's writing is the result of situated knowledge for, as Tobin Siebers notes, "Feminist philosophers have long argued that all knowledge is situated, that it adheres in social locations, that it is embodied, with the consequence that they have been able to claim that people in marginal social positions enjoy an epistemological privilege that allows them to theorize society differently from those in dominant social location."20 Indeed, by placing Arendt on the same plane of imminence as insurgent Black mothers who are explicitly referred to in Reply, we may begin to situate the notoriously famous statement in Crisis, "We must decisively divorce the realm of education from the others, most of all from the realm of public, political life." ${ }^{21}$ Here, in Crisis, the call is decisively clear on Arendt's part that education is to be divorced from the public realm, politics. The rub, as Eduardo Duarte points out, is that Crisis was "written in view of the harsh criticism of her position in Reflections, where she had, in an untimely manner, argued against the forced integration of schools."22

Indeed, Natasha Levinson notes that the publication of "Reflections on Little Rock" was delayed amid wide controversy and eventually published in Dissent, Winter, 1959. ${ }^{23}$ Along with the publication of the original essay, "Reflections," Arendt includes a new prologue, "Preliminary Remarks," and ends with an addendum, "A Reply To Critics." From the "Preliminary Remarks," Arendt states, "I therefore agreed to let Dissent publish the article as it was written - not because I thought that a year-old topical essay could exhaust the subject or even do justice to the many difficult problems involved, but in the hope that even an inadequate attempt might help break the dangerous routine in which the discussion of these issues is being held from both sides." ${ }^{24}$ One prominent player in the debate was Ralph Ellison. As Levinson points out, "After Ralph Ellison criticized Arendt for not understanding the reality of what it meant to be black in America, she changed her mind... [As such, she acknowledges] the argument that black parents had relinquished responsibility for the world needed modification in light of Ellison's critique. Arendt conceded this point some years after the essay had been published, although she did so in a private communication 
with Ellison rather than in a public forum." 25 Arendt eventually comes around to Ellison's criticism, but it is disappointing that she never brought this reexamination of the event to the public domain again for discussion.

If Arendt is projecting her academic self onto the lives in Little Rock, then we might expect this misreading of the actions by Black parents in Little Rock. In Reply, Arendt tells her critics that the genesis of her essay, Reflections, began as she was troubled by a photo, "showing a Negro girl on her way home from a newly integrated school; she was persecuted by a mob of white children...her face bore eloquent witness to the obvious fact that she was not precisely happy." ${ }^{26}$ Arendt anguishes over this photo, as it motivated her desire to write "Reflections." This essay however did not go as intended as it drew sharp criticism, which in turn Arendt replies to her critics, explicitly amplifying the reasons she objected to black children in Little Rock being integrated amid white hostility.

To her critics in Reply, she justifies her claims by situating her motives within the lives of black mothers stating, "My first question was: what would I do if I were a Negro mother? ... [Arendt replies], If I were a Negro mother in the South, I would feel that the Supreme Court ruling... has put my child into a more humiliating position than it had been before... [Next] If I were a Negro mother I would feel that the very attempt to start desegregation in education in schools had not only, and very unfairly, shifted the burden of responsibility from the shoulders of adults to those of the children. I would in addition be convinced that there is an implication in the whole enterprise of trying to avoid the real issue... [And next] If it were only a matter of equally good education for my children, an effort to grant them equality of opportunity, why was I not asked to fight for an improvement of schools for Negro children...?"27 If Arendt were a "Negro mother," she obviously would do a lot as an insurgent to defend and protect the rights of her children. The problem, of course, is that she is neither a Black mother nor the parent to the children she refers to. Indeed, while her efforts at representative thinking - by placing herself in the "shoes of others" - are empathetic efforts, they fall short of the mark. 
Philosopher Sharon Todd details how the use of empathy as a means to rectify social injustices can fall short on two accounts. First, through psychic projection where "the self projects one's own mental state onto another, and second, that there is a question of 'divining' the intricacies of the other's feelings... [Where] the self casts its own life onto that of the other; it is as though it sets up the other to be a reflection of part of the self." ${ }^{28}$ Clearly from the remarks made by Arendt above, Todd's insights pertain: Arendt did project herself onto black mothers in Little Rock, 'divining' what those mothers actually felt. The rub for Todd is that in such a situation, "understanding empathy through projective identification means, it seems to me, that it is not so much about getting to know what the Other is feeling but to recognize one's own projected material... In this regard, putting oneself in the other's shoes can tell us something about ourselves and while this may be valuable... it seems to fall short of the call to responsibility that the Other commands." ${ }^{29}$ Arendt's attempt to empathize with the black mothers of Little Rock falls short from Todd's perspective, as Arendt's efforts to speak for black mothers fails as she sees only what she has projected onto them, rather than actually listening attentively, i.e., learning from them, hence Arendt's efforts falls short of the responsibility that the Other commands.

What do Arendt's comments in Reply tell us about her situation? First, Arendt's character is not at issue here. Rather, the events surrounding the publication of Reflections, with its swarm of controversies, tell us that she clearly misread the event of Little Rock. Second, it tells us that in the very act of responding to her critics to Reflections, Arendt (albeit unconsciously) in Reply, projects onto black mothers, whereby rendering them both hyper-visible as the objects of her empathy, and while simultaneously submerging them in what Fanon refers to as "overwhelming objectivity."

Be that as it may, exhaustion also includes creation. The creation of concepts that are a function of the very perverse anonymity of the event with its "overwhelming objectivity." As the creation of concepts is a function of the problem in the event as such, when Arendt writes about Crisis in education the production of the conception of education as-becoming-decisively-di- 
vorced from the public realm, would seem rather isomorphic with her actions of becoming divorced from the actual event of Little Rock. Indeed, as Eduardo Duarte suggests, "Crisis is of a wholly different nature, coming as it does from a withdrawal from the political realm." 30 As such, in Crisis Arendt had already "withdrawn from the political realm," whereby education is rendered a general concern as Little Rock is not mentioned, but its affect was not forgotten, nor far from her thinking.

\section{BECOMING DECISIVELY DIVORCED \& PHILOSOPHIC CREATION}

Does philosophic creation always occur within a perverse context, i.e., the perverse anonymity of crisis? No. But, it does within the context of anti-black racism, which as Gordon Lewis claims functions within the mundane as a perverse anonymity, a cancelling of Black (and other marginalized) subjectivities in the very light of day, so to speak. If this is so, then perhaps we might think of a site that can mitigate the force of anti-black racism. Indeed, many have already posited such a site: the public school.

But unlike the schools of Little Rock, the school we need is one which becomes decisively divorced from anti-black racism (and other oppressive ontologies), whereby the possibility of philosophic creation can occur for teachers and students alike. To address this specific concern: the school as becoming decisively divorced, suspended (temporarily) from the world, I call your attention to a wonderful and brilliant text by Jan Masschelein and Maarten Simons, In the Defence of the School. ${ }^{31}$ This text captures the spirit of Arendt's conceptualization of education as becoming decisively-divorced from the public realm. Indeed, they argue the temporary divorce of schooling from the public realm ironically allows the student to explore public life and by extension anti-black racism in society more philosophically, hence to become a public issue! Here schooling is radically transformed; it is a time-out to put into "play" the events and crises of the world as moments of study, free of the violence and exhaustion found in actual crisis.

And what event, we may ask, needs to be put into play in schools today? To this point, consider Erin Manning's take on the crisis in diver- 
sity where she declares, "insurgent Black life is neurodiverse through and through. This is its threat, that it cannot be properly regulated, that it exceeds the bounds of the known, that it moves too much...[For as] Moten continues: 'Anti-blackness is anti-life'...[Such] that neurotypicality as a founding identity politics discounts black life implies, at the limit, that it discounts all life, all generative force, all unbounded, unpredictable, rhythmic, insurgent life." 32 As Manning indicates, there are strong conceptual (and political) ties between insurgent Black life and neurodiversity, that exceeds the bounds of the known. Perhaps then, budding philosophers of education might engage this exploration of how diversity functions as a web of singularities, yet is seen as a whole: a disjunctive synthesis?

In the end, our own endeavors as philosophers of education might be viewed as a mode of scholarly activism: an activism always becoming: becoming decisively divorcing, undoing the ties that bind particular concepts to our thinking education. Here perhaps, philosophy of education acts to stimulate crisis, and hence "exhaust" concepts like "neurotypicality" and those violent ontologies that refuse to see that Black lives matter not only in the public/private realms but also at the very heart of philosophical creation.

1 Lewis Gordon, Fanon and the Crisis of European Man: An Essay on Philosophy and the Human Sciences (New York: Routledge Press, 1995),10.

2 Gordon, Fanon and the Crisis of the European Man, 10.

3 Gordon, Fanon and the Crisis of the European Man, 56.

4 Lewis Gordon, What Fanon Said: A Philosophical Introduction to His Life and Thought (New York: Fordham University Press, 2015), 42.

5 Gordon, What Fanon Said, 42.

6 Gordon, What Fanon Said, 49.

7 Gordon, 49. Emphasis in original.

8 Gordon, 49. 
9 Fred Moten quoted in Erin Manning, The Minor Gesture (Durham, NC:

Duke University Press, 2016), 5.

10 Peter Pal Pelbart, "Exhaustion and Creation," in Cartography of Exhaustion (Minneapolis, Mn: Univocal Press, 2015), 120, hereafter referred to as EC.

11 Pelbart, "Exhaustion and Creation,"122.

12 Perlbart, 122, 125.

13 Perlbart, 130.

14 Gilles Deleuze \& Felix Guattari, What is Philosophy? (New York: Columbia University Press, 1994), 2.

15 Deleuze \& Guattari, What is Philosophy? 16

16 See Claire Colebrook, "Disjunctive Synthesis," in The Deleuze Dictionary, ed. Adrian Parr (New York: Columbia University Press, 2005), 77-78.

17 Hannah Arendt, "Reflections on Little Rock," in The Portable Hannah Arendt (New York: Penguin Classics, 2003).

18 Hannah Arendt, "A Reply to Critics," in The Portable Hannah Arendt (New York: Penguin Classics, 2003); Hannah Arendt, "The Crisis in Education," in Between Past and Future (New York: Penguin Books, 1968).

19 Manning, The Minor Gesture, 3.

20 Tobin Siebers, Disability Theory (Ann Arbor: University of Michigan Press, 2010), 22 .

21 Arendt, "Crisis," 162.

22 Eduardo Manuel Duarte, "Educational Thinking and the Conservation of the Revolutionary," Teachers College Record 112, no. 2 (2010): 488.

23 Natasha Levinson, “A 'More General Crisis’: Hannah Arendt, WorldAlienation, and the Challenges of Teaching for the World as It Is," Teachers College Record 112, no. 2 (2010): 468.

24 Arendt, "Reflections," 231. 
25 Levinson, “A 'More General Crisis', 468.

26 Arendt, "Reply," 244.

27 Arendt, 244.

28 Sharon Todd, Learning from the Other (Albany, NY: SUNY Press, 2003), 54.

29 Todd, Learning from the Other, 57. Emphasis mine.

30 Duarte, "Educational Thinking," 488.

31 Jan Masschelein \& Maarten Simons, In Defence of the School: A Public Issue, trans. Jack Mc Martin (Leuven, Belgium: E-ducation, Culture \& Society, 2013).

32 Manning, The Minor Gesture, 4-5. 